\title{
Mihin suomenkielisiä käsitteitä tarvitaan?
}

\section{Taidehistorioitsijat käsite- ja termityössä digiaikana}

\author{
Susanna Aaltonen, Marja-Leena Ikkala, Hanna Kemppi \& \\ Juhana Lahti
}

doi.org/10.23995/tht.112317

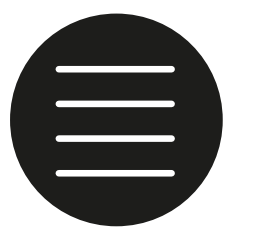

Katsausartikkeli käsittelee Suomessa tehtyä ja tekeillä olevaa taidehistorian ja kulttuuriperinnön käsitetyötä, sen haasteita ja tulevaisuuden näkymiä digiajalla. Esimerkkeinä ovat Museoviraston kulttuuriympäristön ontologiaprojekti ja Tieteen termipankki.

Asiasanat: taidehistorian terminologia, terminologiset sanastot, käsitteet, termit, digitalisaatio, ontologiat, käsitetyö 
Professori Riitta Nikula pohti Taidehistorian seuran julkaiseman Tahiti-lehden kolumnissa tasan kymmenen vuotta sitten, vuonna 2011, opiskelijan esittämää kysymystä: "Voiko gradun kirjoittaa ilman Foucaultia?" Kolumnissaan Nikula teki seuraavan huomion ja kysyi: "Vaikka kansainvälistä tutkimusta on seurattu monelta suunnalta, luettu kieliä ja tehty matkoja, harva suomalainen on kunnostautunut taiteen tutkimuksen käsitteiden kehittämisessä. Miksi?”1

\section{Käsitteistä ja niiden merkityksestä}

Nikulan kysymyksen taustalla voi nähdä yleisemmin 2000-luvulla alkaneen keskustelun käsitteiden merkityksestä. Mieke Bal julkaisi klassikkoteoksensa Travelling Concepts in the Humanities: A Rough Guide vuonna 2002. ${ }^{2}$ Käsitteiden jatkuva muuntautuminen ja liikkuvuus on sen jälkeen ollut selviö. Balin teos on keskeinen viittauksien kohde esimerkiksi kymmenen vuotta myöhemmin, vuonna 2012, ilmestyneessä antologiassa Travelling Concepts for the Study of Culture. ${ }^{3}$ Kirja on mainio lähtökohta pohtia taidehistorian tieteenalan tilannetta Suomessa. Esimerkiksi Helsingin yliopiston Taidehistorian oppiaine siirtyi vuonna 2012 taiteiden tutkimuksen yhteydestä yhdeksi Kulttuurien tutkimuksen osaston tieteenalaksi. Kuten professori Annika Waenerberg on 2010-luvun alkupuolella kiteyttänyt, taidehistoria on taiteen ja visuaalisen kulttuurin moni-, poikki- ja yleistieteistäkin tutkimusta. Viimeistään 1980-luvulta lähtien taidehistoriallisen - ja vastaavasti monien muidenkin humanististen tieteenalojen - tutkimuksen tekemistä ovat muo- kanneet ja ohjanneet sellaiset teoriat, näkökulmat ja menetelmät, jotka ovat lähtöisin taidehistorian ulkopuolelta. ${ }^{4}$ Taidehistorian tieteenalan näkökulma tai paradigma on vaihtunut taiteen määrittelystä kuvan määrittelyyn. Se on toisaalta myös seurausta sekä taiteen käsitteen muutoksesta että kiinnostuksen kohdistumisesta ympäristöön ja kulttuuriperinnön vaalimiseen.

Nikulan kolumnin ilmestymisen jälkeen eri toimijat ovat määritelleet ja analysoineet käsitteitä sekä laatineet termitietokantoja ja terminologisia sanastoja. Tavoitteenamme on kirjoittajien asiantuntemusta yhdistäen ja yhdessä pohtien kartoittaa taidehistorian käsitteiden ja termien parissa tehtävää työtä ja luoda keskusteluyhteys erilaisten tietovarantojen välille. Samalla pohdimme käsitetyön merkitystä ja käsitteiden käyttöä työkaluina, sekä käsitteiden erilaisia soveltamisen tapoja humanistisissa tieteissä ja erityisesti taidehistorian tutkimuksessa ja kentällä. Luonteeltaan ikuisessa prosessissa valmista ja täydellistä ei ole odotettavissa. Tämä ehkä entisestäänkin korostuu esimerkiksi nykyisissä helposti muokattavissa wikiympäristöissä.

Katsauksen kirjoittajista Juhana Lahti on perehtynyt Suomessa 2000-luvun digitaalisen murroksen myötä ajankohtaisiin kysymyksiin. Tietoyhteiskunta, josta on puhuttu useamman vuosikymmenen ajan, alkaa olla todellisuutta. Käsillä on suuri muutos, kun koneluettava rakenteellinen digitaalinen tieto alkaa tulla todelliseksi semanttisen verkon myötä. Tähän kehitykseen liittyy myös sanastojen ontologisointityö. ${ }^{5}$ Hyviä ajankohtaisia esimerkkejä ovat Kulttuurisampo
1 Riitta Nikula, "Voiko gradun kirjoittaa ilman Foucaultia?," Tahiti nro. 1 (2011), https://tahiti.journal.fi/article/ view/85415/44365.

2 Mieke Bal, Travelling Concepts in the Humanities: A Rough Guide (Toronto: University of Toronto Press, 2002).

3 Travelling Concepts for the Study of Culture, edit. Birgit Neumann \& Ansgar Nünning (Boston: De Gruyter, 2012).
4 Annika Waenerberg, "Menetelmämetsiköstä mielekkääseen tutkimusotteeseen," Taidetta tutkimaan, toim. Satu Kähkönen \& Annika Waenerberg (Jyväskylä: Kampus Kustannus, 2012), 10-11.

5 "W3C Standardit", luettu 10.5.2021, http://www.w3c. tut.fi/standards.html. 
ja Biografiasampo. ${ }^{6}$ Lisäksi Lahti pohtii muun muassa analogisen ja digitaalisen suhdetta ja kysyy, pitäisikö analoginen tieto nähdä uudella tavalla aiempaa keskeisempänä kulttuuriperinnön osa-alueena.

Hanna Kemppi tarkastelee Tieteen termipankkia, jonka taidehistorian aluetta hän on koordinoinut vuodesta 2018 . Tieteen termipankki on vuonna 2012 avattu verkkopalvelu. Se on Suomessa harjoitettavien tieteenalojen yhteinen, avoimen tieteen periaatteella toimiva ja jatkuvasti päivitettävä, semanttiseen MediaWikiin perustuva termitietokanta. ${ }^{7}$ Kemppi esittelee Tieteen termipankin periaatteita ja tavoitteita. Hän tuo esille sen, miten sekä työekonomisesti että tieteenalan keskustelun kannalta on tarkoituksenmukaista tutkia yhteistyömahdollisuuksia Suomessa tehtävän muun termi- ja sanastotyön kanssa sekä hyödyntää mahdollisuuksien mukaan puolin ja toisin jo tehtyä työtä.

Museoviraston kulttuuriympäristöpalvelut -osastolla jo useamman vuoden ajan toimineessa ontologiaan ja käsitteiden määrittelyyn keskittyneessä työryhmässä mukana ollut Marja-Leena Ikkala tuo osuudessaan esille tätä ontologiatyötä. Museovirasto käyttää Museoalan ja taideteollisuusalan ontologiaa $(\mathrm{MAO} / \mathrm{TAO})^{8}$ tietojärjestelmissä esimerkiksi rekisterien asiasanoituksessa ja hakutoiminnoissa sekä kokoelmahallinnassa. Kun ontologiaa käytetään esimerkiksi asiasanoituksessa kulttuuriperintöaineistoa digitoitaessa, aineiston löytyminen helpottuu olennaisesti. $\mathrm{Mu}$ seoviraston MAO/TAO:n uusimpaan versioon

"Kulttuurisampo - suomalainen kulttuuri semanttisessa web 2.0:ssa", luettu 8.5.2021. http://www.kulttuurisampo.fi/; "Biografiasampo - Suomalaisten elämäkertojen verkosto semanttisessa webissä", luettu 8.6.2021, https://biografiasampo.fi/.

7 "Tieteen termipankki", https://tieteentermipankki.fi. Tieteenaloistamme noin kolmasosa (noin 50 eri aihealuetta eli tieteenalaa tai erikoisalaa) on tullut mukaan termipankkiin vuoteen 2021 mennessä.

8 "Finto - Suomalainen asiasanasto- ja ontologiapalvelu: MAO / TAO - Museoalan ja taideteollisuusalan ontologia", luettu 10.5.2021, https://finto.fi/maotao/fi/.
(2019) päivitettiin erityisesti kulttuuriympäristön käsitteitä. Näistä suuri osa on selvästi myös taidehistorian käsitteitä, mikä tekee vuoropuhelun esimerkiksi Tieteen termipankin ja Museoviraston ontologiatyön välillä hedelmälliseksi.

Susanna Aaltonen vastaa katsauksen johdannon koostamisesta yhteistyössä muiden kirjoittajien kanssa. Artikkelin lopuksi hän pohtii Taidehistorian seuran roolia ja käsitetyön tulevaisuudennäkymiä keskeisten käsitteiden ja niiden määrittelyn merkityksestä ammentaen sekä esiteltyjä ajankohtaisia kehityskulkuja reflektoiden.

\section{Digiajan haasteet}

Nykypäivän digitalisoituvassa yhteiskunnassa julkisilla varoilla tuotettu tieto halutaan saada mahdollisimman laajaan hyötykäyttöön avoimen saatavuuden ja saavutettavuuden periaatteiden mukaisesti. Datan yhteentoimivuus on ratkaisevaa tämän toteutumisessa. ${ }^{9}$ Yhteentoimivuus edellyttää, että kaikki tietoa käsittelevät tahot ymmärtävät yhteiset käsitteet samalla tavalla ja että informaation merkitys pysyy samana, kun tietoa siirretään eri tietojärjestelmien välillä. ${ }^{10}$ Käsite- ja sanastotyö on tärkeä osa tätä kokonaisuutta. Koneluettavuus puolestaan edellyttää datalta rakenteellisuutta, jotta sitä voidaan jäsentää. Datan rakenteellisuudella on erilaisia tasoja, ja jokainen kehitysaskel eteenpäin edistää asiaa. ${ }^{11}$

Kun puhutaan digiajasta, puhutaan analogisen muuttumisesta digitaaliseksi sekä kokonaan uudenlaisista digitalisaation mahdollistamista toimintatavoista. Digitalisaation alun määrit-

9 "Tiedon yhteentoimivuus", luettu 19.8.2021, https:// vm.fi/tiedon-yhteentoimivuus.

10 "Rakennetun ympäristön tiedon yhteentoimivuus", luettu 19.8.2021, https://ym.fi/yhteentoimivuus.

11 Marcia L. Cheng esittää jaottelun structured, semi-structured and unstructured data. Marcia L. Cheng, "Semantic Enrichment for Enhancing Historical and Cultural Heritage Data to Support Digital Humanities Research", luettu 24.4.2021, https://seco. cs.aalto.fi/events/2020/2020-12-11-heldig-summit/ ZengML-DHSummit20.pdf. 


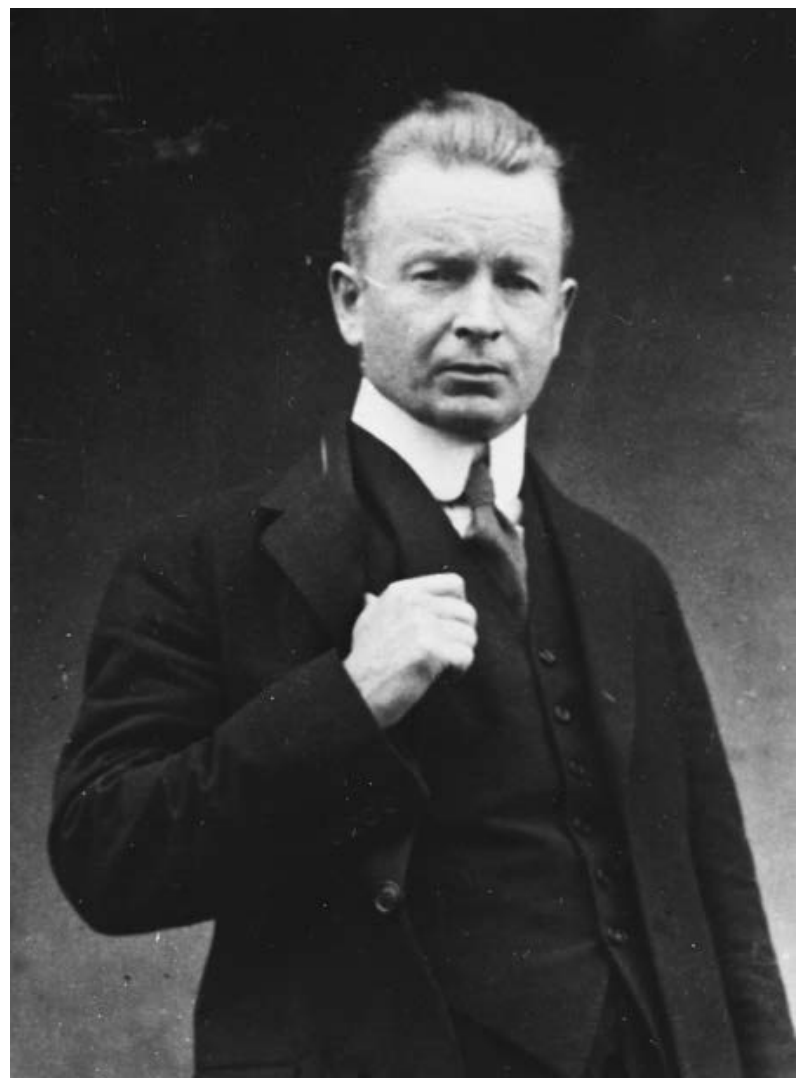

Kuva 1. Museovirasto julkaisi vuodenvaihteessa Finnassa yli 200000 valokuvaa, jotka ovat kaikkien vapaasti käytettävissä. Mukana oli muun muassa valokuva Eliel Saarisesta (1873-1950). Kuva: Historian kuvakokoelma / Museovirasto. Finna.fi (haettu 10.9.2021).

täminen ei ole yksiselitteistä: mikroprosessori tuli markkinoille 1970-luvulla, ensimmäiset CAD-suunnitteluohjelmat 1980-luvulla ja Internet löi läpi 1990-luvulla. Digitalisaation alkuaikoina kyse oli suuren yleisön näkökulmasta ennen kaikkea laitteiden digitalisoitumisesta. Kotitietokoneet ja digitaalikellot olivat 1980-luvun uusia massatuotteita siinä missä digikamerat vuosituhannen vaihteessa. Jo olemassa olevien laitteiden digitaalisten versioiden lisäksi syntyy kokonaan uusia laitteita ja laitteiden hybridejä. Digitaalikellossakin oli laskin vakiovarusteena ja nykyaikainen mobiililaite kaikkine toimintoineen on tästä hyvä esimerkki.

Digitalisaatio voidaan jakaa erilaisiin vaiheisiin, joista digitointi eli analogisen muuttaminen di- gitaaliseksi on ensimmäinen tai ensimmäisiä. ${ }^{12}$ Valokuvien digitointi on tästä hyvä ja museoille tuttu esimerkki siinä missä painettujen julkaisujen digitointi tiedeyhteisölle. ${ }^{13}$ Digitalisoinniksi voidaan kutsua digitaalisten välineiden tai digitaalisen tiedon eli datan tuottamista. Digitalisaatioksi taas täsmällisemmässä merkityksessä ihmisten ja tietojärjestelmien vuorovaikutusverkon toteutumista, joka on parhaillaan ajankohtainen.

Käsillä olevaan kehitysvaiheeseen liittyy myös datafikaatio eli datan merkityksen ja kaupallisen arvon korostuminen kaikkialla yhteiskunnassa. Vuonna 2019 voimaan tullut tietosuoja-asetus (GDPR) on EU:n reaktio tähän tilanteeseen, jossa jokainen mikrosirun sisältävä laite kerää dataa. Kyse on esineiden internetistä eli siitä, kuinka laitteet kommunikoivat keskenään. Jo lähitulevaisuudessa siintää vaihe, jossa perinteisesti eri paikoissa sijaitsevaa tietoa kyetään yhdistämään digitaalisesti. Yhtenä tavoitteena on luoda yhteensopivan datan verkosto yhteiskunnan eri toimijoiden kesken. Parhaillaan laaditaan ra-

12 Ville Rintala erittelee digitalisaation vaiheet seuraavasti:

1) Digitointi, joka tarkoittaa analogisen muuttamista digitaaliseksi (valokuvien digitointi)

2) Digitalisointi, joka liittyy digitaalisten välineiden kehittymiseen (kaupallinen internet, verkkosivustot, hakukoneet jne, digikamerat). (Web 1.0 Luettava internet)

3) Digitalisaatio, joka merkitsee ihmisten ja tietojärjestelmien vuorovaikutusverkon toteutumista eli tietoyhteiskuntaa siinä mielessä, kun siitä on viime vuosikymmenet puhuttu (asiakas- ja palvelukeskeisyys, datan merkitys korostuu). (Web 2.0 vuorovaikutteinen internet)

4) Digitaalinen murros / muutos, joka tulee tarkoittamaan rakenteisen tiedon toteutumista. (Web 3.0 semanttinen internet).

Ville Rintala, "Digitalisaatio muuttaa kaiken" - Digitalisaatio suomalaisten teollisuusyritysten ja yhteiskunnan kontekstissa. Markkinoinnin ja viestinnän akateeminen yksikkö, Digitaalisen median pro gradu -tutkielma, Viestinnän monialainen maisteriohjelma, Vaasan yliopisto (2021), 19-25, https://osuva.uwasa. fi/bitstream/handle/10024/12212/UVA_2021_Rintala_Ville.pdf?sequence=2\&isAllowed=y.

13 Esim. 2019-2020 digitoidut Taidehistorian seuran julkaisut. "Julkaisut", luettu 22.8.2021, http://www.taidehistorianseura.fi/fi/julkaisut/. 
kennetun ympäristön tietojärjestelmää ja siihen liittyen kulttuuriympäristön tietomallia. ${ }^{14}$ Tämä verkottuva tieto nostaa tietoyhteiskunnan aivan uudelle tasolle, kun tieto saadaan aikaisempaa laajemmin hyötykäyttöön. Tämä myös vapauttaa resursseja, kun samaa tietoa ei tarvitse ylläpitää useammassa paikassa samanaikaisesti. Olemme muutoksen äärellä.

Digitalisaatio-termiä ei löytynyt syyskuun alussa 2021 Tieteen termipankista. Tämä kertoo osaltaan siitä, että analogisen ja digitaalisen yhteensovittamisessa on vielä paljon tehtävää. Muistiorganisaatioiden näkökulmasta keskeinen kysymys on, kuinka kaikki edeltävä eli historiallinen tai analoginen saadaan mukaan kehitykseen ja digitaalisesti saavutettavaksi eli haettavaksi, käytettäväksi ja hyödynnettäväksi. Analoginen tieto tulee todennäköisesti säilymään digitaalisen rinnalla ikuisesti, mutta on huolehdittava siitä, että aikojen kuluessa kertynyt tieto saadaan mahdollisimman laajasti digitaalisesti saavutettavaksi. Aiemmin tutkittu, testattu ja koettu tai koeteltu on olennaista saada mukaan uuteen tiedon verkottuneeseen kokonaisuuteen. Analoginen tieto olisikin aiheellista nähdä nykyistä laajemmin osana vaalittavaa kulttuuriperintöä sekä muistiorganisaatioissa että korkeakouluissa.

\section{Tieteen termipankki}

Tieteen termipankin toiminta lähtee ajatuksesta, että (etenkin ihmis)tieteissä pidetään tärkeänä hallita tieteellistä tiedonmuodostusta ja tiedeviestintää sekä suomeksi / ruotsiksi että englanniksi ja muillakin tieteenalan perinteisillä kielillä. Termien ymmärtäminen ja hallinta osana tiettyä teoriakehystä, näkökulmaa ja tieteellistä diskurssia vakiintuneine ilmaisukonventioineen - jotka eri kielissä saattavat poiketa toisistaan - nähdään olennaisena osana asiantuntijuutta ja tieteen-

14 Ympäristöministeriön Ryhti-hanke: "Ryhti-hanke", luettu 10.5.2021, https://ym.fi/ryhti; Ryhti-hanketta edeltänyt KiraDigi: "KiraHub, luettu 10.5.2021. https:// kirahub.org/info/. tekemistä. Työskentely termipankissa perustuu kohdennetun asiantuntijaryhmän rajoitettuun talkoistamiseen (niche sourcing) ${ }^{15}$, joka erottaa sen esimerkiksi Wikipediasta. Rajoitetulla talkoistamisella tarkoitetaan tässä yhteydessä, että ainoastaan kunkin tieteenalan vapaaehtoisten asiantuntijoiden (pääsääntöisesti tohtoreiden ja väitöskirjatutkijoiden) on mahdollista muokata omaa tieteenalaansa koskevaa termistöä. Muut aiheesta kiinnostuneet voivat osallistua sivujen keskustelutoiminnon avulla. ${ }^{16}$

Taidehistorian aihealuetta perustettaessa asiantuntijaryhmä, johon kuului termipankkiin rekisteröityneitä taidehistorian tutkijoita, määritteli aluksi termien luokitteluperiaatteita. Wikiympäristössä yksi termi voi olla yhtä aikaa useammassa eri luokassa, mikä osaltaan luo kiinnostavaa verkostoa termien välille. Perustaksi valittiin kirjastoalan UDK-luokitusta mukailevat luokat, mutta tarvittaessa voidaan luoda myös muita, tieteenalan ja aihealueen kannalta tarkoituksenmukaisia luokkia. Esimerkkinä on "taidehistorian peruskäsitteet", johon on ryhdytty kokoamaan sellaista sanastoa, jota on totuttu omaksumaan esimerkiksi taidehistorian peruskursseilla. Luokituksilla on olennaista merkitystä jo käsiterakenteen tukena, mutta esimerkiksi opetuksen kannalta on käytännöllistä, että tiettyyn luokkaan kuuluvat termit voidaan jakaa linkkinä.

Google Analyticsin mukaan termipankkiin tehdään arkisin lukukausien aikana noin 5000 päivittäistä käyntiä ja sisältönä on jo kaikkiaan noin 43000 käsitesivua. Yksittäisten tieteenalojen käsitesivujen määrä kuitenkin vaihtelee pal-

15 "Tieteen termipankki: Avoin tiede: talkoistaminen", luettu 28.4.2021, https://tieteentermipankki.fi/wiki/ Avoin_tiede:talkoistaminen.

16 Aiheesta ovat viimeksi laajemmin kirjoittaneet Johanna Enqvist ja Tiina Onikki-Rantajääskö: Johanna Enqvist \& Tiina Onikki-Rantajääskö, "Tieteen monikielinen termistö yhteisöllisenä toimintana korkeakouluopetuksessa," Kieli, koulutus ja yhteiskunta 12 nro. 2 (2021), https://www.kieliverkosto.fi/fi/journals/kieli-koulutus-ja-yhteiskunta-maaliskuu-2021/tieteen-monikielinen-termisto-yhteisollisena-toimintana-korkeakouluopetuksessa. 


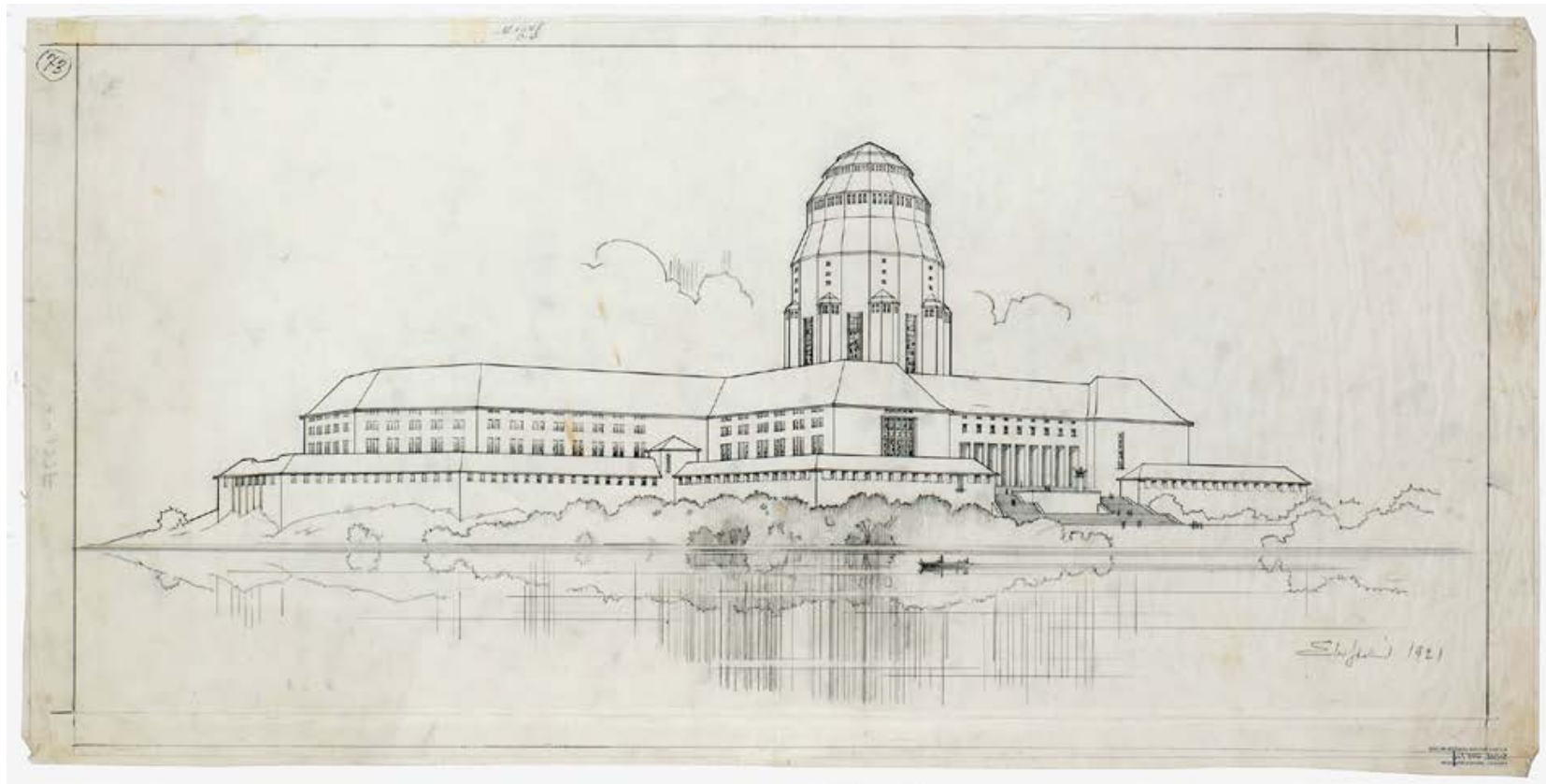

Kuva 2. Arkkitehtuurimuseo avasi viime toukokuussa Eliel Saarisen piirustuskokoelman sen tekijänoikeuden päätyttyä keväällä 2021. Kuvassa Kalevalatalo-suunnitelma (1921) Munkkiniemeen. Piirustus: Eliel Saarinen / Arkkitehtuurimuseo. Finna.fi (haettu 10.9.2021).

jon: pisimpään mukana olleilla aihealueilla sivuja on jo jopa 6000, monilla 10-200. Luonnollisesti olennaisinta on sivujen sisältö. Taidehistorian aihealueella on vuoden 2021 alkuun mennessä noin 600 käsitesivua, joissa on pyritty tuottamaan aina sekä termin määrittely, selite, käsitehierarkiaa että useita erikielisiä vastineita.

Verrattuna joihinkin kauan termipankissa mukana olleisiin tieteenaloihin taidehistoria on alana suhteellisen pieni. Yhtäältä meillä on vähemmän asiantuntijaresursseja, mutta toisaalta on ehkä helpompi saada kokonaiskäsitys Suomessa tehtävästä ja tehdystä tutkimuksesta ja keskusteluista sekä opetuksen painotuksista eri yliopistoissa. Alan suhteellinen pienuus ei ole este hedelmälliselle käsitekeskustelulle, jota voidaan käydä esimerkiksi julkaisuissa, Taidehistorian seuran piirissä ja Tieteen termipankissa. Termien pohdinta ja kehittäminen on myös tulevaisuuteen katsomista ja oman alan kehittämistä.

Termipankin vahvuuksina ovat esimerkiksi monitieteisyys ja tieteellisen keskustelun lisääminen, heikkouksina pysyvän rahoituksen puute ja rajoitetun talkoistamisen vaikeudet, esimerkiksi asiantuntijoiden passiivisuus ja kiireisyys. Nämä tulivat esiin myös syksyllä 2019 termipankin toteuttamissa asiantuntijaryhmien jäsenille ja laajemmin käyttäjille suunnatuissa kyselyissä, joiden tulokset on julkaistu Tieteessä tapahtuu -lehdessä. ${ }^{17}$

Kyselyjen yleishavainto oli positiivinen: keskeneräisyydestään huolimatta termipankilla on jo vakiintunut asema tutkijoiden, opettajien ja opiskelijoiden työkaluna. Termipankkia käytetään eniten tiedonhakuun (noin $30 \%$ ), opiskeluun (18\%) ja tutkimukseen (11\%). Yhteisöllisyys ei kuitenkaan vielä toteudu. Vastuu tieteenalan

17 Johanna Enqvist, Kaarina Pitkänen-Heikkilä \& Tiina Onikki-Rantajääskö, "Tieteen termipankki tiedeyhteisön työkaluna," Tieteessä tapahtuu 38 nro. 4 (2020): 25-32. https://journal.fi/tt/article/view/98121. Samojen kirjoittajien vertaisarvioitu analyysi ilmestyy 2021: "Terminology Work as Open, Communal and Collaborative Crowdsourcing Practice of Academic Communities," Terminology (Special issue: Terminology as a Societal Resource:Possibilities and Responsibilities in a Changing World) 27 no. 1. 
termistön ajantasaisuudesta ja kartuttamisesta samoin kuin laadukkaan ja oikeellisen tiedon tuottamisesta voi olla vain tieteenalan omilla toimijoilla. Kukaan muu ei voi tuottaa tätä valmiina palveluna.

Uusien aihealueiden perustamisvaiheessa on ollut säätiörahoituksella määräaikaisia koordinaattoreita, mutta silti termipankki ei ole perinteinen tutkimushanke täysipäiväisine työntekijöineen. Se on uudenlaisen toimintatavan muoto, joka herättelee pohtimaan esimerkiksi, miten termityöstä voisi muodostua osa tutkimus- ja opetustyön rutiineja. ${ }^{18}$ Opetus- ja tutkimushenkilöstö voi ainakin Helsingin yliopistossa kohdentaa työaikaansa Tieteen termipankkiin. ${ }^{19}$ Väitöskirjatutkijat voivat saada termityöstä opintopisteitä, ja vaikka termipankkijulkaisuilla ei toistaiseksi ole Jufo-luokitusta, voi ne julkaisuluettelossa sijoittaa esimerkiksi ammatillisten julkaisujen luokkaan. ${ }^{20}$ Taidehistorian seuran tuki on olennainen, sillä kuten käyttäjäkyselyjen toteuttajat havaitsivat, parhaiten termityö on edistynyt aloilla, joissa tieteellinen seura on tukenut työn aloittamista ja varmistanut sen jatkuvuutta. ${ }^{21}$

Vaikka Tieteen termipankkia nimensä mukaisesti kartuttavat ennen kaikkea tieteentekijät, yksi kiinnostava taidehistorian aihealueen yhteistyösuunta voisi esimerkiksi olla museomaailma. Museoiden kokoelma- ja näyttelytyössä sekä tarvitaan luotettavia termi- ja käsitetietokantoja että pohditaan termikysymyksiä ja saatetaan tuottaa tai vakiinnuttaa uusiakin termejä. Taidehistorian aihealue on hyötynyt esimerkiksi

18 Ibid.

19 Helsingin yliopiston kieliperiaatteet (2014), 12. http:// hdl.handle.net/10138/160446.

20 "Tieteen termipankki: Termityön merkitseminen tutkimustietojärjestelmään ja julkaisuluetteloon", luettu 28.4.2021, https://tieteentermipankki.fi/wiki/ Termity\%C3\%B6n_merkitseminen_tutkimustietoj\%C3\%A4rjestelm\%C3\%A4\%C3\%A4n_ja_julkaisuluetteloon.

21 Enqvist, Pitkänen-Heikkilä \& Onikki-Rantajääskö, Tieteen termipankki tiedeyhteisön työkaluna, 32.
Museoviraston ylläpitämän museoalan ja taideteollisuusalan erikoisontologian (MAO/TAO) kehittämistyöstä. Ontologiatyö tukee hyvin termipankkia esimerkiksi keskustelussa käsitesuhteista ja -hierarkiasta, vaikka se ei tuotakaan termien laajempia selitteitä, joita voitaisiin suoraan hyödyntää termipankissa.

Taidehistorian aihealue on vielä monin tavoin keskeneräinen, ja monet keskeiset termit ovat niin sanotusti suuria ja vaikeita, määrittelyjä pakeneviakin. Termit karttuvat pankkiin yksittäin tai pieninä ryhminä. Puutteiden havaitsemisen voi nähdä kutsuna keskusteluun ja tekemään täydennyksiä. Yksi kiinnostava termipankin ominaisuus on, että myös vakiintumattomia, keskustelunalaisia tai ristiriitaisia termejä voidaan käsitellä. Se myös osoittaa, etteivät termit muodosta vain yhden tieteenalan sisäistä rihmastoa vaan ovat monitieteisessä vuorovaikutuksessa. Koska termien tunnistaminen ja analyysi tapahtuu usein tutkimuksen osana ja tiedeyhteisön keskusteluissa, ehkä voisimme pohtia, millaisissa oman tutkimus- ja opetustyömme prosesseissa jo teemme termityötä. Tätä olisi mahdollista tuoda näkyväksi myös Tieteen termipankissa.

\section{Ontologia- ja käsitetyötä Museovirastossa}

Museovirasto vastaa Museoalan ja taideteollisuusalan ontologian sisällön kehittämisestä. Tämän ontologian pohjana on Museoalan asiasanasto (MASA), joka julkaistiin 1997 ja ontologisoitiin vuonna 2004 osana FinnONTO-projektia. Ontologia on kuvaus tarkasteltavan alueen käsitteistä ja niiden välisistä suhteista. Suhteet voivat olla hierarkkisia, assosiatiivisia tai koostumussuhteita. Käsitteistö esitetään koneluettavassa muodossa niin, että sitä voidaan käyttää tietojärjestelmissä ja kokoelmanhallinnassa. Tavoitteena on erilaisten aineistojen sisällönkuvailun ja löydettävyyden parantaminen.

Ontologiaa kehitettiin erityisesti kulttuuriympäristön kuvailun tarpeisiin vuosina 2017-2019. 
Tässä opetus- ja kulttuuriministeriön rahoittamassa projektissa toimi konsulttina Sanastokeskuksen terminologi Päivi Kouki. ${ }^{22}$ Projektissa tarkennettiin ja täydennettiin hierarkioita sekä lisättiin noin 2000 kulttuuriympäristön käsitettä, joita nykyisin on yhteensä yli 5000. Koko MAO/ TAOssa on kaikkiaan noin 13000 käsitettä. Kulttuuriympäristön käsitteet ovat osa Museoalan ontologiaa, joten niitä ei voi tarkastella irrotettuna koko ontologiasta. Hierarkia-rakenteen vuoksi MAOssa on myös Yleisen suomalaisen ontologian (YSO) käsitteitä.

Käsitteiden täydentämisen ja tarkistamisen lisäksi Museovirastossa laadittiin suomenkieliset määritelmät noin 200 ontologian käsitteelle. Nämä määritelmät ovat lyhyitä terminologisia määritelmiä. Lisäksi ontologiaan lisättiin $\mathrm{Eu}$ rooppalaisen kulttuuriperintöpolitiikan sanastosta poimittuja määritelmiä noin 100 käsitteelle. ${ }^{23}$ Ontologiaan on aiemmin lisätty myös Kiinteistöja rakentamisalan keskeinen sanasto (Versio 1.0) -julkaisun ${ }^{24}$ käsitteet määritelmineen. Ontologian uusin versio sisältää yli 400 kulttuuriympäristökäsitteen määritelmää.

Tarve täydentää Museoalan ontologian kulttuuriympäristökäsitteitä tuli selväksi jo vuonna 2008, kun Museovirastossa alettiin määritellä Euroopan neuvoston HEREIN-verkoston ${ }^{25}$ laatiman monikielisen kulttuuriperintöpolitiikan tesauruksen noin 600 käsitettä. Tesaurus on asiasanasto, jossa ilmaistaan myös asiasanojen suhteet.

22 Sanastokeskus ry tarjoaa sanasto-, luokitus- ja ontologiatyöhön sekä erikoisalojen termien käyttöön liittyvää tietoa ja asiantuntijapalveluita, luettu 23.8.2021, www.tsk.fi/; Museoviraston kulttuuriympäristöosaston työryhmää täydennettiin Rakennustaiteen museon edustajalla.

23 "Eurooppalaisen kulttuuriperintöpolitiikan sanasto", luettu 10.5.2021, https://www.museovirasto.fi/uploads/Arkisto-ja-kokoelmapalvelut/Julkaisut/kulttuuriperintopol-sanasto.pdf.

24 "Kiinteistö- ja rakentamisalan keskeinen sanasto", luettu 10.5.2021, kira-sanasto_1.0.pdf (kiradigi.fi).

25 "HEREIN: Heritage Network, Council of Europe", luettu 10.5.2021, https://www.coe.int/en/web/culture-and-heritage/herein-heritage-network.
Monikielinen tesaurus laadittiin helpottamaan kansainvälistä yhteistyötä ja tekstien kääntämistä. Suomen osuus julkaistiin myös edellä mainittuna Eurooppalaisen kulttuuriperintöpolitiikan sanastona. Kun Museoviraston työryhmässä pohdittiin termien käännöksiä ja määritelmiä, aiheuttivat Euroopan maiden erilainen lainsäädäntö ja asiantuntijaorganisaatioiden toimintatavat vaihtelua niin termien käyttöön, sisältöön kuin niiden hierarkkisiin suhteisiinkin. Sen vuoksi Suomen lainsäädäntöön ja kulttuuriympäristöasiantuntijoiden toimintatapoihin perustuvaa ontologiaa pidettiin tärkeänä.

Museoalan ontologia on merkittävä osa Finto. fi-palvelun KOKO-ontologiaa, jota ylläpitää Kansalliskirjasto. Pitkälti aineistojen kuvailuun tarkoitettu Museoalan ontologia on laajasti käytössä Suomen museoissa. Finto.fi on käytössä myös Finna-palvelussa. Opetus- ja kulttuuriministeriö, jonka tulosohjauksessa Museovirasto toimii, tukee Museoalan ontologian kehittämistä.

Valtion hallinnossa kulttuuriympäristöt kuuluvat ympäristöministeriön vastuulle, joten Museovirasto toimii tiiviissä yhteistyössä myös ympäristöministeriön kanssa. Viime vuosina julkinen hallinto on ottanut käyttöön niin sanotun yhteentoimivuusalustan yhteentoimivien tietosisältöjen määrittelyyn. ${ }^{26}$ Tiedonhallinnassa ja tietovirroissa tarvittavien tietomallien ja koodistojen lisäksi alusta tarjoaa Sanastot-työkalun. Julkisen hallinnon määritteleviä terminologisia sanastoja julkaistaan Sanastot-alustalla ${ }^{27}$, ja erityisesti rakennetun ympäristön sanastot ovat tärkeitä kulttuuriympäristön kannalta. Näillä sanastoilla on ohjaava vaikutus, joten Museovirasto tarkistaa, että Museoalan ontologiassa julkaistavat määritelmät ovat samoja kuin Sanastot-alustalla. Museovirasto on tarpeen mukaan mukana ympäristöministeriön työryhmissä, kuten esimerkiksi

"Yhteentoimivuusalusta", luettu 10.5.2021, https://dvv. fi/yhteentoimivuusalusta.

27 "Sanastot", luettu 10.5.2021, https://sanastot.suomi. fi/. 
kun määriteltiin rakennusperinnön suojelun käsitteitä. ${ }^{28}$ Finto.fi- ja Sanastot.suomi.fi-palvelun ylläpidossa ja kehittämisessä on tärkeää välttää päällekkäistä työtä ja varmistaa, että määritelmät ovat yhtenäiset.

Kulttuuriperinnön laajamittainen digitalisointi herättää huolta ja kysymyksiä aineistojen löydettävyydestä, ja pelko aineistojen katoamisesta määrittelemättömään bittiavaruuteen on motivoinut ontologiatyön tekemistä. Käsitteiden keskinäisten suhteiden jäsentely on sujunut osin vauhdilla, toisinaan taas hyvinkin vaivalloisesti, erityisesti kun erotellaan viranomaistyön arjessa helposti synonyymisesti käytettäviä käsitteitä, kuten esimerkiksi rakennusperintö ja rakennettu kulttuuriympäristö. Viranomaistyötä tekeville on tärkeää, että käsitteiden merkitykset ovat yhteisiä. Kun merkitykset yritetään puristaa lyhyiksi terminologisiksi määritelmiksi, on Sanastokeskuksen terminologin panos ollut keskeinen. Ryhmän jäsenillä on taipumus pohtia ja keskustella näistä varsin pitkään ja välillä kiivastikin. Keskustelun tarvetta selittää se, että sekä termien ontologisointi että määrittely vie oman alan perusasioiden äärelle ja antaa mahdollisuuden miettiä käsitteitä, kun arkityössä niitä vain käytetään. Käsitteiden merkitykset myös muuttuvat lainsäädännön, tutkimuksen ja kulttuuriympäristöalan kehittymisen myötä eli työ jatkuu. Korjailtavaa ja täydennettävää on niin ontologiassa kuin käsitteiden määrittelyssäkin.

\section{Käsitetyön tulevaisuus}

Marcel Proust viittaa jäätyneillä kuvilla siihen, että kirjassa liian tarkkaan kielellisesti kuvaillulle ja määritellylle henkilölle ei jää liikkumavaraa. ${ }^{29}$ Jäätyneillä tai jähmettyneillä käsitteillä ei myös-

28 "Rakennusperinnön suojelun käsitteitä", luettu 18.8.2021, https://sanastot.suomi.fi/concepts/ $16506 f$ f-a5fd-43bf-b28e-afce1 bb030ac.

29 Ks. Johanna Vuorelman kommentti Marko Junkkarin artikkelissa. Marko Junkkari. Helsingin Sanomat 7.3. 2021, luettu 6.5.2021, https://www.hs.fi/sunnuntai/ art-2000007842328.html. kään tiede voi mennä eteenpäin. Käsitteet eivät koskaan tule lopullisesti määritellyiksi. Siinä missä teoriat ovat jähmeitä ja kokonaisvaltaisia yksittäiset käsitteet ovat joustavampia, ja voivat tulla määritellyiksi aina uudelleen. Oikeastaan ne jopa tulee ja pitää määritellä jokaisessa tutkimuksessa tapauskohtaisesti. Mihin sitten tarvitaan esimerkiksi tieteenalojen yhteistä Tieteen termipankkia ja vieläpä suomeksi 2020-luvun globaalissa ja kansainvälisessä maailmassa?

Termipankkia ja käsitetyötä tarvitaan keskustelun pohjaksi ja ylläpitämiseksi, käsitteiden jäätymisen estämiseksi ja matkan jatkumiseksi. Kuten yllä tuli ilmi, digitaalinen murros ja erilaiset tietovarannot vaativat jatkuvaa päivitystä. Esimerkiksi Tieteen termipankin kokoamisen haasteet ovat talkootyön periaate ja kentän asiantuntijoiden pieni määrä ja työtilanne. Kokopäiväisessä työssä olevat eivät ehdi talkoisiin. Ne, jotka ehtisivät joutuvat kamppailemaan toimeentulostaan, eikä ilmaista talkootyötä ehkä ehdi tehdä sen takia. Artikkelimme alussa siteerattu Nikulan kolumni on edelleen valitettavan ajankohtainen myös sen humanististen alojen arvostusta ja työllisyyttä pohtivin osin: "Nyt ei enää koetella vain oppiaineiden rajoja, talouskriisi uhkaa kaikkia humanistisia aloja." ${ }^{30}$ Tämä uhka on toteutunut yliopistoissa 2010-luvulla surullisella tavalla, kuten viimeaikainen julkisuus humanistisen tiedekunnan resurssipulasta ja Taiteiden tutkimuksen neuvottelukunnan julkilausuma osoittavat. ${ }^{31}$

Kun pula on pahin, on hyvä edetä strategisesti. Käsitteet voidaan jakaa paitsi tärkeisiin ja vähemmän tärkeisiin, myös helppoihin ja vaikeisiin ja toisaalta historiallisiin ja täysin uusiin. Käsitetyönkin voi jakaa kolmenlaiseen työhön. Yhtäältä on järkevää kartuttaa ja laajentaa esimerkiksi

30 Riitta Nikula, "Voiko gradun kirjoittaa ilman Foucaultia?".

31 Taiteiden tutkimuksen asemaa tiedeyliopistoissa parannettava, Taiteiden tutkimuksen seurojen neuvottelukunnan julkilausuma 23.4.2021. Taidehistorian seura, luettu 6.5.2021, http://www.taidehistorianseura. fi. 
Tieteen termipankkia rivakasti helpoimmilla käsitteillä, joita yksittäiset asiantuntijat voivat tehdä oman erikoisosaamisensa puitteissa itsenäisesti. Toisaalta myös täysin uudet käsitteet, kuten alussa mainittu digitalisaatio, olisi hyvä saada pian käyttöön. Kolmanneksi on ilman muuta tarpeellista keskittyä vaikeisiin taidehistorian historiallisiin ydinkäsitteisiin, sellaisiin kuin kaanon, tyyli, kuva, konteksti, representaatio. Nämä tärkeät ja aina ajankohtaiset ydinkäsitteet vaikuttavat tosin myös kaikkein haastavimmilta. Niitä on pohdittu ja niiden pohdintaa olisi mielekästä edelleen jatkaa yhdessä. Ne ovat kuitenkin käsitteitä, joita ilman tai joita tiedostamatta ei voi pro gradu -tutkielmaa kirjoittaa. Laajasta suomalaisen kontekstin huomioivasta termipankista, samoin kuin muistakin alan sanastoista, on iloa ja hyötyä koko taidehistorian piirille: niin opiskelijoille kuin varttuneille tutkijoille.

Taidehistorian seuran rooli on seuran sääntöjen mukaisesti "toimia taidehistorian ja taiteentutkimuksen edistämiseksi Suomessa. Tarkoituksensa toteuttamiseksi yhdistys voi järjestää kokouksia ja esitelmätilaisuuksia sekä harjoittaa julkaisutoimintaa." Taidehistorian seura on ollut mukana käsitetalkoissa kannustamalla muun muassa jatko-opiskelijoita mukaan. Seuran julkaisema Tahiti-lehti on yhteinen foorumi, jossa käsitetyötä tehdään artikkelien muodossa. Lehden sivuilla voi myös jatkaa käsitteistä keskustelua yleisemmin.
Keskustelussa on hyvä muistaa, että sanasto- ja käsitetyö on jatkuva prosessi, eikä se tule kokonaan valmiiksi. Määrittelytyön eteenpäinviemisellä on kuitenkin merkitystä tieteessä ja kulttuuriperinnön käytännön vaalimisessa. Termipankin ja yhteiskäyttöisten sanastojen laajentuessa tieteiden väliset rajat madaltuvat ja esimerkiksi eri toimialojen väliset erot selkeytyvät ja kohtaamiset helpottuvat.

FT, dos. Susanna Aaltonen on perehtynyt erityisesti muotoilun ja arkkitehtuurin historiaan. Hän on opettanut taidehistoriaa Helsing in yliopistossa, Aalto-yliopistossa ja Avoimessa yliopistossa. Hän on Taidehistorian seuran puheenjohtaja.

FM, väit. Marja-Leena Ikkala on Museoviraston Itä- ja Pohjois-Suomen kulttuuriympäristöpalvelut -yksikön intendentti.

FT Hanna Kemppi työskentelee Turun yliopistossa taidehistorian yliopisto-opettajana. Hän on perehtynyt erityisesti ortodoksisen kirkkoarkkitehtuurin ja -taiteen historiaan sekä venäläiseen ja karjalaiseen kulttuuriperintöön.

FT, dos. Juhana Lahti työskentelee erikoistutkijana Museovirastossa Kulttuuriympäristöpalveluiden ohjaus- ja tuki -yksikössä. Hän on perehtynyt erityisesti 1900-luvun loppupuolen arkkitehtuurin ja kaupunkisuunnittelun historiaan sekä digitalisaatioon liittyviin kysymyksiin. 